Annals of Warsaw University of Life Sciences - SGGW

Land Reclamation No 44 (1), 2012: 35-45

(Ann. Warsaw Univ. of Life Sci. - SGGW, Land Reclam. 44 (1), 2012)

\title{
Linkage of "Lakes Zwenkau-Cospuden" as one of the elements of land reclamation after the open-cast mines and its future importance for the development of the region
}

\author{
KATARZYNA GABRYŚ \\ Department of Geotechnical Engineering, Warsaw University of Life Sciences - SGGW
}

\begin{abstract}
Linkage of "Lakes Zwenkau-Cospuden" as one of the elements of land reclamation after the open-cast mines and its future importance for the development of the region. The open-cast mine "Böhlen", closed in 1921, in 1969 was transformed into "Zwenkau"("Zw") open-cast mine. In the seventies, together with its smaller neighbouring mine "Cospuden"("Cs"), became one of the greatest enterprises of the Central German lignite mining area. In the last centuries $\mathrm{Zw}$ and $\mathrm{Cs}$ mines had an significant influence on the economic, technical and scientific progress of this region. Although the mines were in separate mining areas, very close relations of proximity existed between them, particularly in the superposition of the lowering ground water areas. Thus, the total mass of the mine tailings "Cospuden" in the mining sector "Zwenkau" was flattened and designed for land reclamation. Since the cessation of lignite mining in the area Böhlen/Zwenkau/Cospuden the south region from Leipzig has been changed fundamentally. The remaining holes, which mines left behind, became lakes. Along the lakes raised beaches, ports and holiday houses. Lusatia and Central German Mining Administration Company (LMBV), which is now responsible for the reclamation and rehabilitation of disused mines, proposed a new perspective of this region, perceived as a part of nature and human-being. The main emphasis has been placed on the development of created lakes, flow-up phase and good water quality assurance. Some of the new lakes are connected together with artificial canals and locks. This also relates to "Zwenkau-Cospuden Lakes" (LMBV 2009). In this article the methods of management former mining areas in the South from Leipzig, with the great accent put on the linkage of "Lakes Zwenkau-Cospuden", are described. Necessary test on the soil samples from
\end{abstract}

this field are explained. Finally, the influence of the restoration of the area on the development of the region is shown.

Key words: open-cast mines, land reclamation, artificial canal, "Lakes Zwenkau-Cospuden".

\section{INTRODUCTION}

Discovery of coal in the area located south from Leipzig has been known since the $17^{\text {th }}$ century. In 1671 between Rositz and Meuselwitz the first brown coal was found. Drilling in the area Böhlen/Zwenkau date back from the year 1860 (Fig. 1). Around 1870 civil engineering activities began in Gaschwitz, Großstädteln and on the eastern edge of Zwenkau and surface mining was left behind. In 1910, for the first time, a large-scale geological survey took place and from 1919, on the behalf of Saxon State law, geological and hydrological report were elaborated regularly. Then, the Saxon corporation (ASW) was commissioned for the preliminary planning of the brown coal mine in Böhlen as a location of public utility in West Saxony. In 1921 the exploration works for the conveyor bridge in the mine "Böhlen" started. After long digestion phase, only in 1930, the bridge "Böhlen I" could be put into operation. Unfortunately, be- 


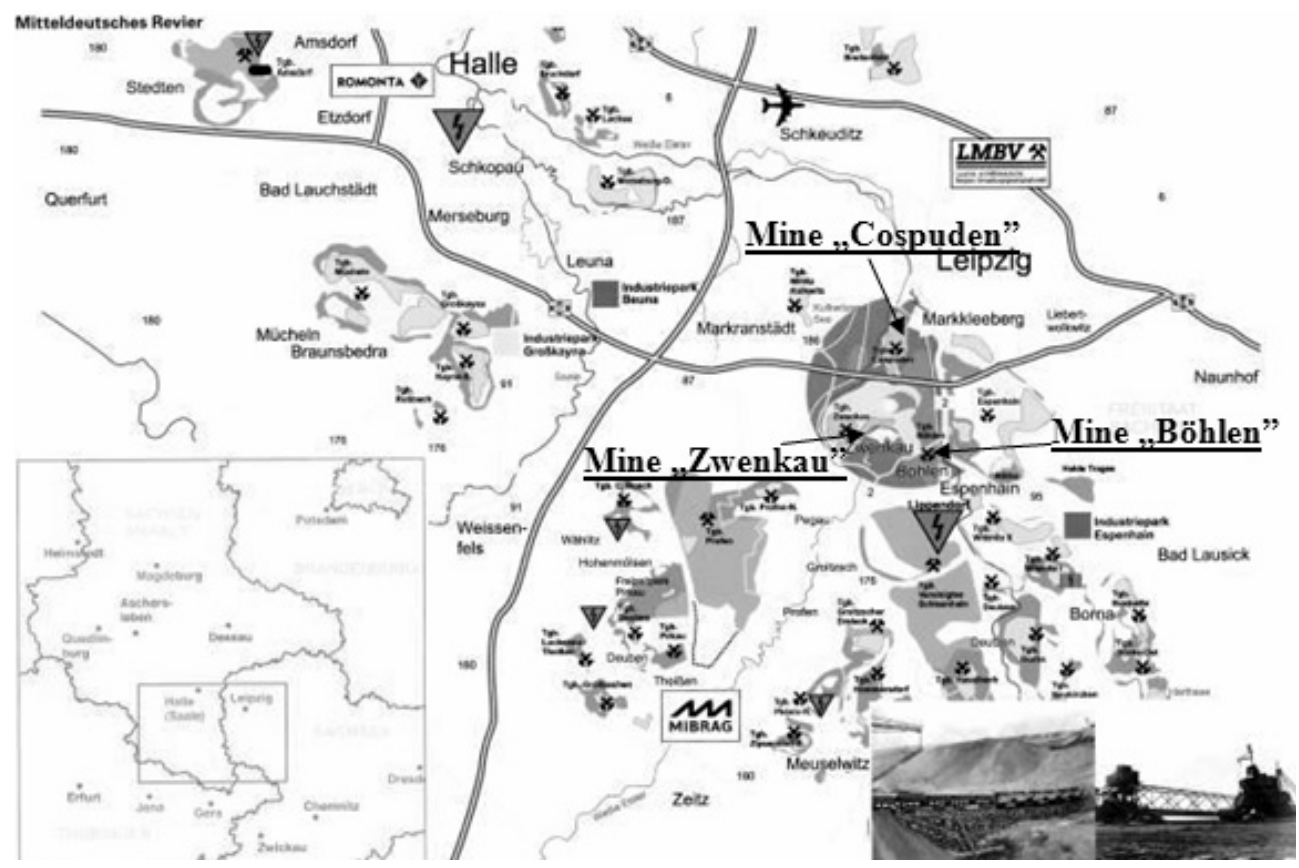

FIGURE 1. Mining industry in the region of Leipzig (1860)

cause of the strong thundersquall, it collapsed on the $12^{\text {th }}$ of May 1937 and two years later was replaced by its greater successor "Böhlen II".

In 1969 the mine "Böhlen" was renamed "Zwenkau", but without any significant alterations in operating regime. A multitude of technological innovations improved the security conditions in the mine. In the early 1980 s came to the largest local relocation of the German Democratic Republic, what caused imposition of remediation requirements for the open-cast mine. At the time of political and economic changes the mine went through a phase of reorganization with the aim of its closing until 1999 and subsequent land reclamation. Embankments made of the excavation material and tailings were used to protect and form the new mining landscape (Fig. 2). The tech- nology from the disused mine "Cospuden" was implemented here in order to reduce the deposits from the conveyor bridge. From 1994, the mine was leased to the United Schleenhain MIBRAG mbH Company. In December 1998, the conveyor bridge went out of service. The mine " $\mathrm{Zw}$ ", as a last mine located in the Central Germany under the management of LMBV, was shut down on the $30^{\text {th }}$ of September 1999.

In "Cospuden" open pit, the youngest and shortest-lived in the South of Leipzig, from 1981 until 1992 coal trains were tumbled. Approximately 87 million cubic meters of excavated earth must have been moved so that 32 million tons of coal could be mined. The outcrop of the mine began on the $1^{\text {st }}$ of April 1981 with the widening of the northern escarpment edge of "Zwenkau" mine. 


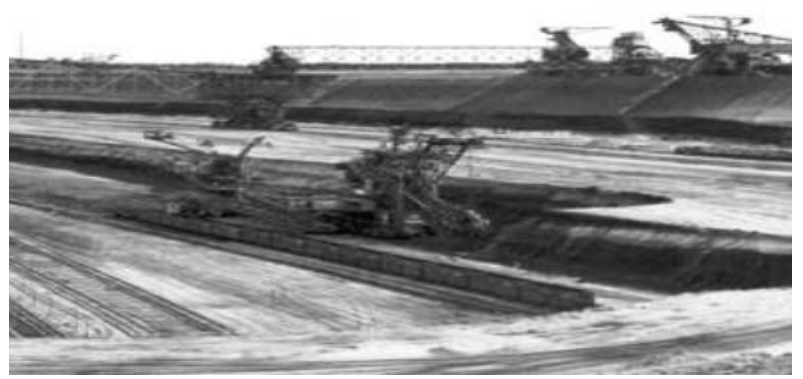

FIGURE 2. Former open pit mining operation in mine "Zwenkau" (1994)

Coal mining started in late August 1981 and achieved a great success, so as the by the bucket "1470" (Fig. 3). Nine years regular operations of the mine, initially later a broad resistance against the con- with a limited set of precut, were halted. tinuation of mining at the construction The closure plan for the redevelopment site No. III ("Cs" open-cast mine) was of the pit was prepared and handed it on formed. In January 1990 the citizens' the $30^{\text {th }}$ of September 1991 to the mininitiative "Stop Cospuden" was founded ing office Borna. In October 1992 the

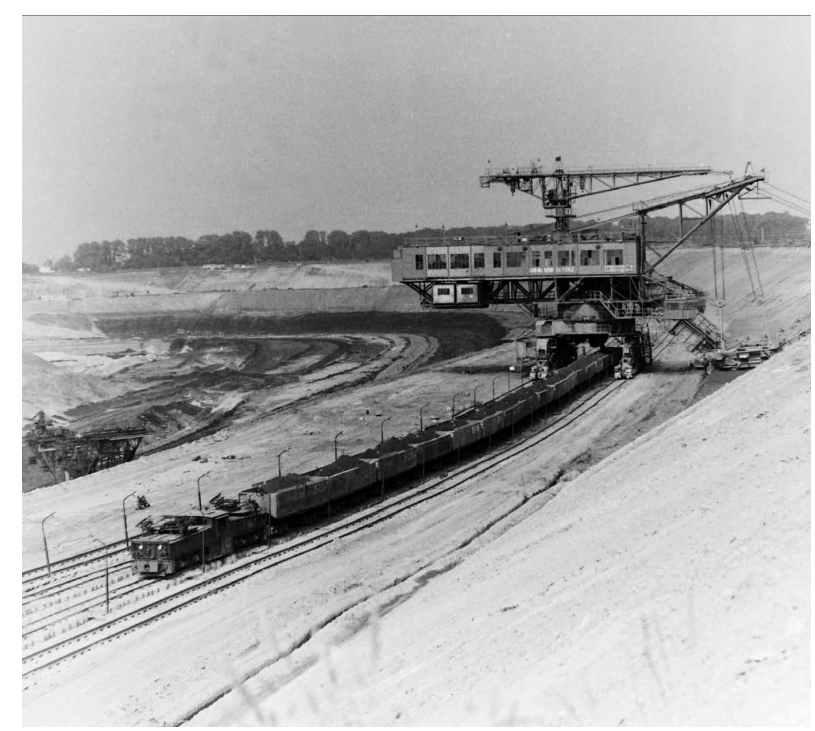

FIGURE 3. Traction mode while excavating in mine "Cospuden" (1985) 
last coal train left the mine and from this moment extensive renovations began (LMBV 2009).

In this paper the methods of recultivation former open mines landscape are presented. The most important results of the land reclamation of this region are outlined, as well as some future plans for its further development. The great emphasis is placed on the connection between two lakes: "Zwenkau" and "Cospuden", on which works began in 2009 and be will continuing until 2014.

\section{METHODS OF LAND RECLAMATION}

Already in the last years of the coal mining giant equipment were used to shape the reminder hole "Zwenkau" for the planned water resource. The mine was being prepared for its closure in the early nineties, when first restructuring measures were initiated. According to the documents of Lusatia and Central German Mining Administration Company (LMBV 2009) this enabled preparations for the flooding on the basis of the final operating plan.

Due to the location of the extraction area of the outskirts of Leipzig, after the end of mining, German Democratic Republic (GDR) arranged to fill the abandoned open pit with water and create touristic spot as well as resting place. The core idea was in the revitalization of the mining environment, water production and involvement of new water in the field with its proper maintenance. On the $10^{\text {th }}$ of October 1991 the formal plan for the redevelopment was presented to the relevant Mining Office. A consequence of co-operation between mining company, regional planning and science was to find a solution for decoupling of the redevelopment both mines and the establishment of the local band company in Zwenkau. In September 1999 LMBV took the responsibility of the mining law for the entire mine. Since that time the necessary rehabilitation works started with more power and great speed (Figs. 4 and 5). In the Table 1 the efficiency of land restoration in the region Zwenkau/ /Cospuden is summarized.

One of the basic recovery method of the post-mining land was rapid flooding. By flooding the abandoned open pit "Lake Cospuden" was formed. An important aspect of this operation was normalization of the hydrological balance. The idea taken under consideration was natural filling the reminder holes by rising the groundwater level. Slow velocity of flooding with complex rehabilitation of the embankments were also essential. However, it turned out that in the area located south from Leipzig, suitable water flow is very limited for a foreign flooding. The solution of this problem was active usage of water comes from the former draining of the mines. This concept was a brilliant chance for reusing the open-cast mine "Cospuden" in a reasonable period of time. An acceptable water quality was also required. In Summer 2000 lake reached its final water level with neutral water conditions and on the $1^{\text {st }}$ of June 2000 was formally opened to the public. Since that moment it started to be one of the most attractive recreational areas in the region of Leipzig.

The idea of flooding the past open pit was also exploited in the case of " $\mathrm{Zw}$ " mine. In April 2006 the filling of "Lake 


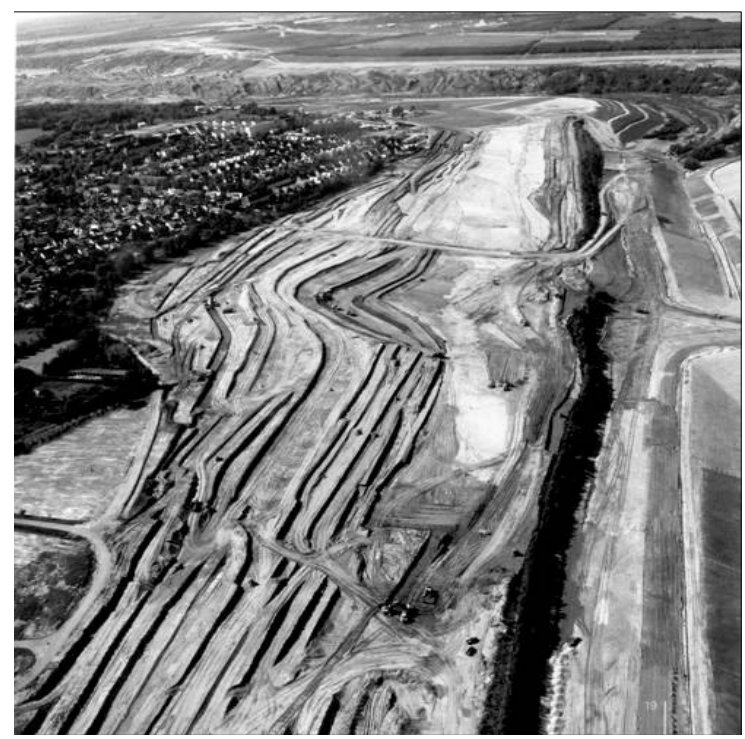

FIGURE 4. Assurance of the banks of the future "Zwenkau Lake"(2005)

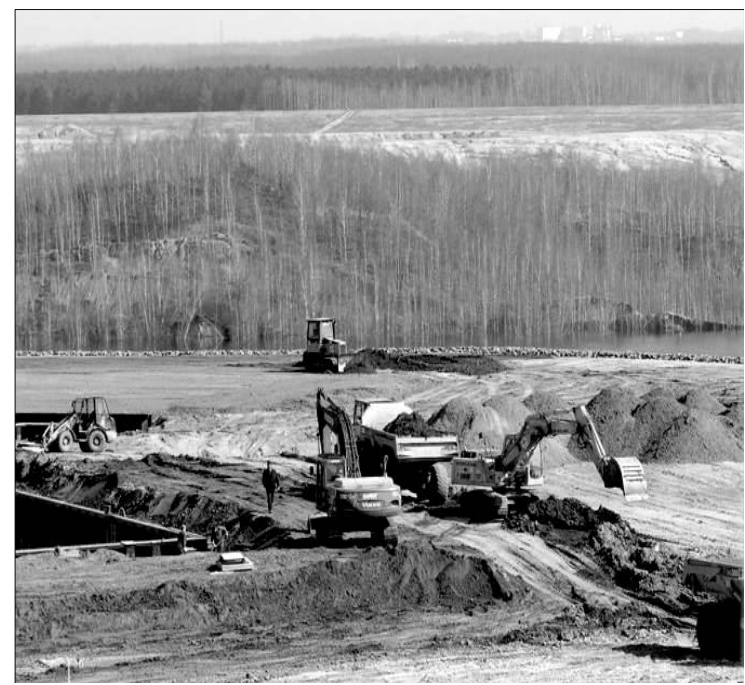

FIGURE 5. Redevelopment in the former mining "Zwenkau" (2009)

Zwenkau" began (Fig. 6). The construction of the drain "Zwenkau-West" from the water pipeline from the open pit Profen, remote around $20 \mathrm{~km}$ away, gave the possibility for creating fast foreign flooding. The achievement of the final water stage is expected in the year 2014. A vol- ume of the lake, after flooding, should reach the top of 174 million cubic meters. To ensure the water quality and compliance with the flood terms, the water from the river White Elster (right tributary of river Saale) is being used as well until the end of 2011. "Lake Zwenkau" in the 
TABLE 1. Land restoration in the area Zwenkau/Cospuden

\begin{tabular}{|l|c|}
\hline Activity & $1994-2008$ \\
\hline Mass movement & 25.6 Million $\mathrm{m}^{3}$ \\
\hline Mass compaction & $1.9 \mathrm{Tm}^{3}$ \\
\hline New agricultural lands and forests & $455.4 \mathrm{ha}$ \\
\hline Decommissioning, dismantling and scrapping & $78.000 \mathrm{t}$ \\
\hline Water collection, purification and derivation & $89.1 \mathrm{Million} \mathrm{\textrm {m } ^ { 3 }}$ \\
\hline Water discharges from foreign flooding & $7.4 \mathrm{Million} \mathrm{m}^{3}$ \\
\hline Building works, demolition & $114.8 \mathrm{Tm}^{3}$ \\
\hline Backfilling of mine openings & $77.6 \mathrm{Tm}^{3}$ \\
\hline
\end{tabular}

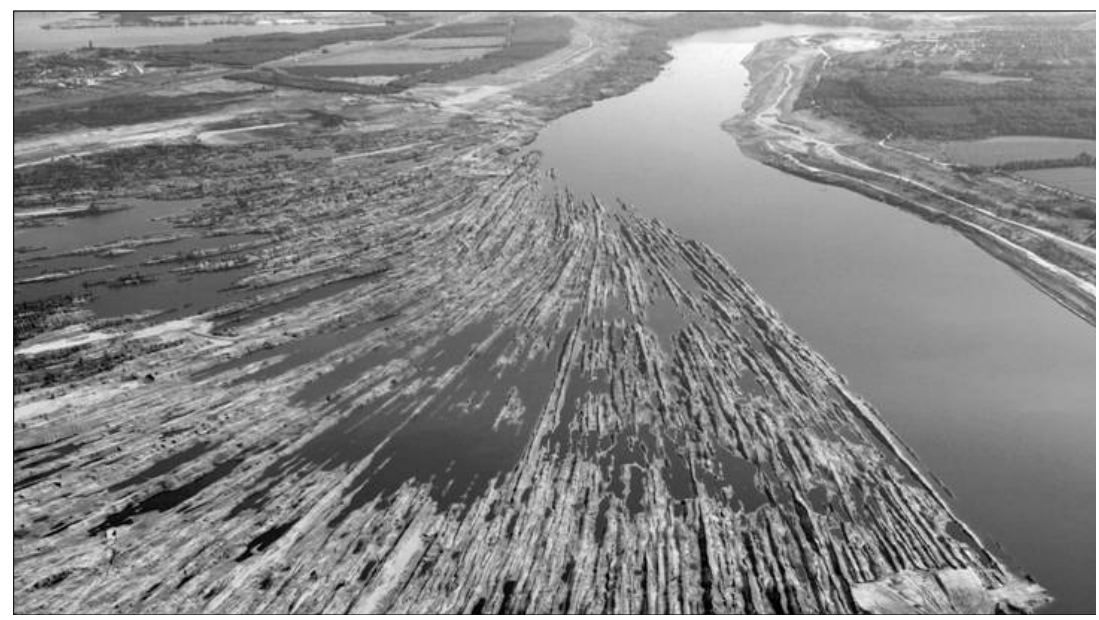

FIGURE 6. Open-cast mine "Zwenkau" while flooding (2006)

coming years becomes a lake with high level of flood protection and developed recreation function (LMBV 2009).

\section{LINKAGE OF "LAKES ZWENKAU-COSPUDEN"}

One of the elements of land reclamation after open-cast mines is construction of connection between "Zwenkau Lake" and "Cospuden Lake" (Fig. 7). Owing to this project, a boat ride from Cospuden over to Markkleeberger and continue to Störmthal will be possible within several years. By the year 2014, the approximately 24 square kilometers of the large lakes landscape, just south of Leipzig, should be shaped. The post-mining lakes: "Cospuden", "Markham", "Störmthal" and "Zwenkau" should be linked by means of channels, splices between themselves and the rivers: White Elster and New Luppe. Finally, a large-scale water connection is expected.

In the Table 2 basic information about a future merger between the lakes are given and on the Figure 8 a plan for the connection is presented (Götz 2010). 


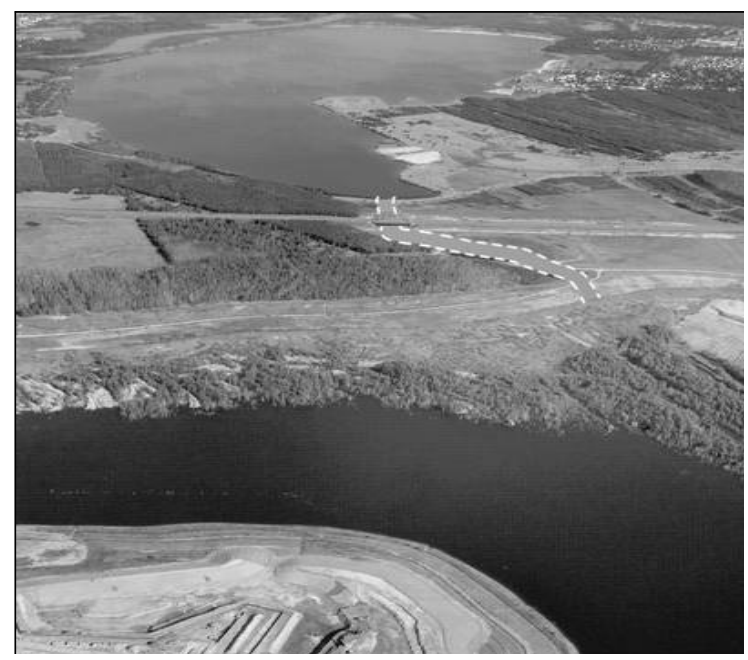

FIGURE 7. Future lakes' connection; in the front "Zwenkau Lake"; in the back "Cospuden Lake" (2009)

TABLE 2. Data concerning linkage between "Lakes Zwenkau-Cospuden"

\begin{tabular}{|l|c|}
\hline Name & Canal with bridges and sluice \\
\hline \multirow{2}{*}{ Length } & Canal \\
\hline \multirow{2}{*}{ Bottom width } & trapezoidal cross section $9.0 \mathrm{~m}$ \\
\cline { 2 - 3 } & rectangular profile $11.0 \mathrm{~m}$ \\
\hline Average depth of the water & trapezoidal cross section $32.0 \mathrm{~m}$ \\
\hline Length of trough structure under A38 & rectangular profile $11.0 \mathrm{~m}$ \\
\hline & around $2.0 \mathrm{~m}$ \\
\hline Length & around $40.0 \mathrm{~m}$ \\
\hline Recoverable length of casing & $51.25 \mathrm{~m}$ \\
\hline Chamber width & $29.0 \mathrm{~m}$ \\
\hline Height of stroke & $6.5 \mathrm{~m}$ \\
\hline Upper offshore terminal & $3.0 \mathrm{~m}$ \\
\hline Lower offshore terminal & around $50.0 \mathrm{~m}$ \\
\hline \multicolumn{2}{|c|}{ around $50.0 \mathrm{~m}$} \\
\hline Bridge Zwenkau & span length $11.0 \mathrm{~m}$, width $8.0 \mathrm{~m}$ with flood \\
\hline Bridge Cospuden & control \\
\hline Headroom of both bridges & in planning \\
\hline
\end{tabular}




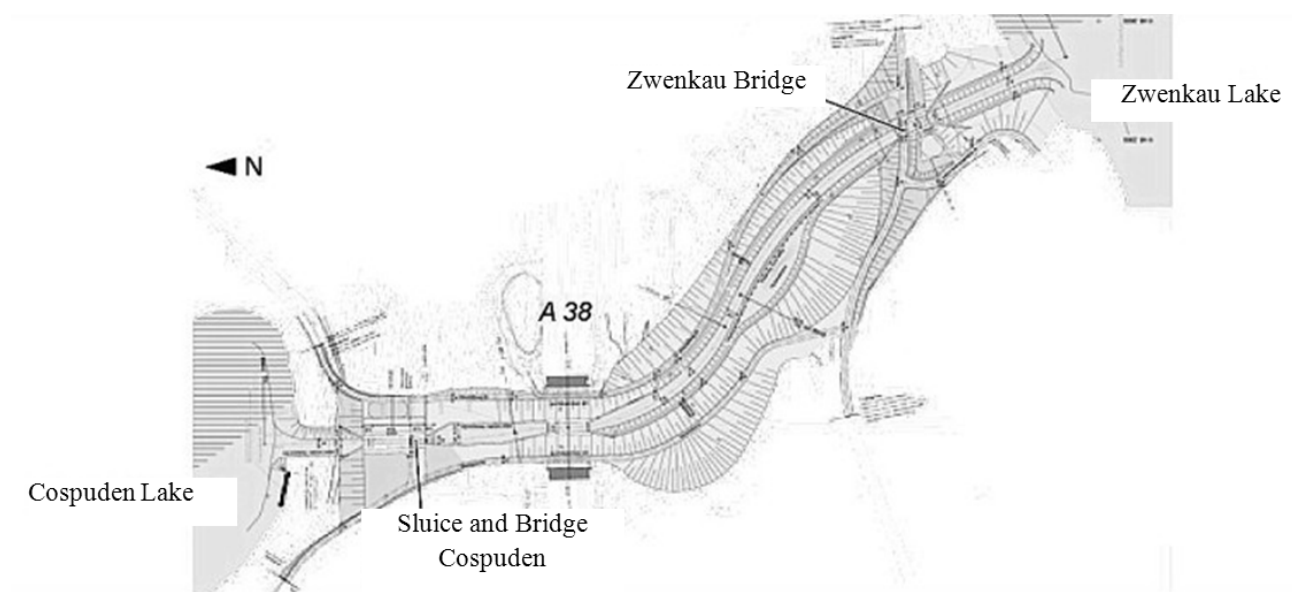

FIGURE 8. Plan of the future lakes' linkage (2009)

In the study of soil for construction of that connection over two lakes, the Geotechnics Institute, from Technical University-Mining Academy in Freiberg has been involved. In order to determine the mechanical properties of the soils, located in the considered land area, 16 drilling holes were performed. Destroyed soil samples, composed mostly of sand and around $40 \%$ of silt, were delivered to the Institute's laboratory. Before the relevant laboratory experiments, specimens were respectively compacted in Proctor Apparatus. Tests, which are inducted to the Institute, are following:

- sieve analysis and organic matter contents;

- permeability analysis;

- oedometer tests;

- triaxial tests: 14 samples CD procedure (consolidated-drained), 6 samples CU procedure (consolidated-undrained);

- liquefaction tests.

All the laboratory analysis are carried out on the loose soils and compacted specimens.

\section{RESULTS AND FUTURE PLANS}

In the $20^{\text {th }}$ century, the destiny of city Zwenkau was defined by the powerful coal. The coal mining formed significantly its development. With the closure of the mine, a completely new perspective opened to the city. Repair works were part of everyday life in Zwenkau, but the concept hidden behind was very simple: city on the lake. In the beginning, no one believed in this vision. In 1999, planners, investors and renovators started an active co-operation, in order to realize their dream with a common effort. The opening of a mining industry pavilion at "the Cape Zwenkau" in April 2006 was only beginning. From the sun terrace of the pavilion it was possible to observe the expansion of a rising harbour. "The Cape Zwenkau" was situated directly to a new urban centre on future "Zwenkau Lake". Colourful sails, excursion steamer, the gondolas floating on the lake, visitors relaxed in the harbour, on the beach or in the holiday villages - those were plans and expectations since land restorations began in the area Zwenkau-Cospuden, which had been mostly successfully fulfilled. 
In 2008, the passenger ship "Santa size of 970 acres is recognized as the Barbara" had its first cruise on the "Lake largest lake located on the south from Zwenkau" (Fig. 9) and became a unique Leipzig and the second largest in Saxand widely popular attraction. "Zwenkau ony. Until 2014 the whole lake should Lake" is the youngest in the region of be released to the public (Guderitz et al. Leipzig which produces water. With the 2009).

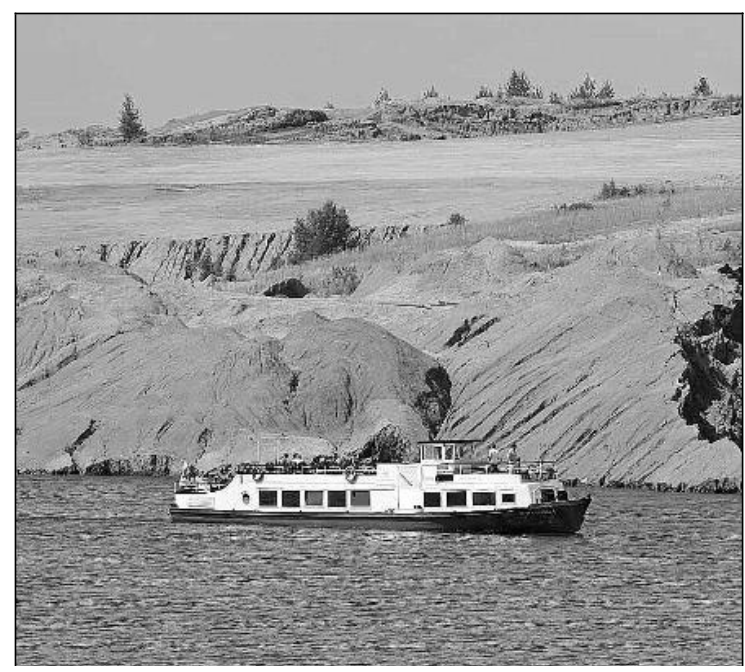

FIGURE 9. "Santa Barbara" - first cruise (2008)

TABLE 3. Some of the results from the laboratory experiments and schedule of further testing

\begin{tabular}{|c|c|c|c|c|c|c|c|c|c|}
\hline \multirow{3}{*}{$\begin{array}{l}\text { Number of } \\
\text { bore hole }\end{array}$} & \multirow{3}{*}{$\begin{array}{l}\text { Drilling } \\
\text { meter }\end{array}$} & \multirow{3}{*}{$\begin{array}{c}\text { Aim: oven-dry } \\
\text { density }\end{array}$} & \multirow{3}{*}{$w_{n}$} & \multirow{2}{*}{\multicolumn{3}{|c|}{\begin{tabular}{|c|}
$\begin{array}{c}\text { Sample preparation in } \\
\text { Proctor } 100 \mathrm{~mm}\end{array}$ \\
$\begin{array}{c}\text { Oven-dry density vs. number } \\
\text { of blows }\end{array}$ \\
\end{tabular}}} & \multirow{3}{*}{$\begin{array}{c}\text { Permeability } \\
\text { Stress in } \\
\text { consolidation } \\
\text { process }\end{array}$} & \multicolumn{2}{|c|}{ Triaxial test } \\
\hline & & & & & & & & \multirow{2}{*}{$\begin{array}{c}\text { Test } \\
\text { method }\end{array}$} & \multirow{2}{*}{$\begin{array}{c}\text { Stress in } \\
\text { consolidation } \\
\text { process }\end{array}$} \\
\hline & & & & \begin{tabular}{|l|}
10 \\
blows
\end{tabular} & 15 blows & 20 blows & & & \\
\hline & {$[\mathrm{m}]$} & {$\left[\mathrm{g} / \mathrm{cm}^{3}\right]$} & {$[\%]$} & \multicolumn{3}{|c|}{$\left[\mathrm{g} / \mathrm{cm}^{3}\right]$} & {$\left[\mathrm{kN} / \mathrm{m}^{2}\right]$} & & {$\left[\mathrm{kN} / \mathrm{m}^{2}\right]$} \\
\hline \multirow{4}{*}{ LB 16} & $\begin{array}{c}5 \\
10\end{array}$ & $\begin{array}{l}1.5 \\
1.6\end{array}$ & $\begin{array}{l}20 \\
26\end{array}$ & $\begin{array}{l}1.640 \\
1.596\end{array}$ & $\begin{array}{l}1.643 \\
1.617\end{array}$ & $\begin{array}{l}1.644 \\
1.624\end{array}$ & & $\begin{array}{l}\text { CUI } \\
\text { CUI }\end{array}$ & $\begin{array}{l}50 / 100 / 150 \\
50 / 100 / 150\end{array}$ \\
\hline & 12 & 1.75 & 18 & 1.757 & 1.772 & 1.788 & 100 & & \\
\hline & 20 & 1.45 & 27 & 1.532 & 1.538 & 1.546 & & CUI & $50 / 100 / 150$ \\
\hline & 21 & 1.5 & 23 & 1.588 & 1.593 & 1.597 & 200 & & \\
\hline \multirow{4}{*}{ LB 15} & 5 & 1.4 & 27 & 1.520 & 1.525 & 1.528 & & CUI & $50 / 100 / 150$ \\
\hline & 6 & 2.05 & 27 & 2.080 & 2.115 & 2.125 & & CUI & $50 / 100 / 150$ \\
\hline & 12 & 1.35 & 25 & 1.540 & 1.545 & 1.549 & & CUI & $50 / 100 / 150$ \\
\hline & 14 & 1.5 & 22 & 1.629 & 1.632 & 1.632 & 150 & & \\
\hline \multirow{3}{*}{ LB10 } & 10 & 1.5 & 28 & & & & & CUI & $50 / 100 / 150$ \\
\hline & 11 & 1.5 & 24 & & & & 100 & & \\
\hline & 18 & 1.5 & 23 & & & & & CUI & $50 / 100 / 150$ \\
\hline \multirow{3}{*}{ LB11 } & 13 & 1.5 & 23 & & & & & CUI & $50 / 100 / 150$ \\
\hline & 14 & 1.5 & 21 & & & & 150 & & \\
\hline & 18 & 1.5 & 20 & & & & & CUI & $50 / 100 / 150$ \\
\hline \multirow{3}{*}{ LB14 } & 7 & 1.63 & 27 & & & & & CUI & $50 / 100 / 150$ \\
\hline & 15 & 1.7 & 23 & & & & & CUI & $50 / 100 / 150$ \\
\hline & 18 & 1.7 & & & & & 150 & & \\
\hline LB16 & 6 & 1.75 & 15 & & & & & Freiberger & 100 \\
\hline LB11 & 17 & 1.5 & 25 & & & & & Freiberger & 150 \\
\hline \multirow{5}{*}{ LB 1} & $5-6$ & 1.45 & 22 & & & & & CUI & $50 / 100 / 150$ \\
\hline & $12-13.5$ & 1.45 & 27 & & & & & CUI & $50 / 100 / 150$ \\
\hline & 7 & 1.5 & 24 & & & & 100 & & \\
\hline & $13-13.5$ & 1.5 & 27 & & & & 150 & & \\
\hline & 14 & 1.3 & 29 & & & & 200 & & \\
\hline
\end{tabular}


There are still several conceptions waiting for being completed. Apart from the linkage between "Lakes Zwenkau-Cospuden", part of the plans are:

- a holiday village separated by a small wooded area;

- a hotel;

- around 400 vacation houses with full facilities;

- 30 floating holiday houses.

The partial results from the laboratory experiments conducted by the Geotechnics Institute, from TU Freiberg are summarized in the Table 3.

\section{CONCLUSIONS}

The region located south from Leipzig: Zwenkau and several villages in its vicinity, as well as large agricultural lands and forests, fell victim to the brown coal mining. Through the land reclamation after mining became possible regaining these territories and giving them a new form. The rehabilitation works in the former open pit "Cospuden", completed in 2000, made the "Cospuden Lake" an established tourist area. "Lake Zwenkau" has been lately also earning more beautiful shapes. The banks are safe and prepared for future uses. Cruise along the lakes makes achievable to marvel wonderful landscape. The harbour "Zwenkau" is largely completed - only water is still missing and north shore is being developed gradually. Despite many projects, around $90 \%$ of the banks remain freely accessible. By the connection of "Lakes Zwenkau-Cospuden" tourists will gain not only the opportunity of recreation on the rivers, but also the possibility to admire the beauty of the nature and to in- tercourse directly with her. The dream of a vacation on the river with its own Jetty can be a reality soon (TV Sächsiches Burgen- und Heldeland e.V. 2010).

Where once villages had to lose ground because of the mines, today new opportunities open up, chances for an urban development in a totally different landscape. What 20 years ago seemed like a utopia, now is getting true (Leipziger Neuseenland 2010).

\section{Acknowledgement}

Participation in the project was possible thanks to a scholarship received by the German organization DBU "Deutsche Bundesstiftung Umwelt" in the period 01.03.2011-31.08.2011.

\section{REFERENCES}

GÖTZ M. 2010: Geotechnischer Bericht [Geotechnical Report]. KUBENS Ingenieurgesellschaft $\mathrm{mbH}$, Beratende Ingenieure.

GUDERITZ I., ULRICH K.U., NITSCHE C. 2009: Der Zwenkauer See südlich von Leipzig vom Tagebau zum Wassersportund Erholungszentrum [Lake Zwenkau south from Leipzig from mining to water sports and recreation center]. BGD GmbH Dresden. BWK-Bundeskongress, 17-19.09.2009.

Leipziger Neuseenland. 2010: Aus dem Herzen der Stadt ins südliche Leipziger Neuseenland [From the heart of the city into the southern Leipzig Lake]. Stadt Leipzig. Amt für Stadtgrün und Gewässer.

LMBV Lausitzer und Mitteldeutsche Bergabu-Verwaltunggesellschaft mbH. 2009: 04 Wandlungen und Perspectiven. Böhlen/Zwenkau/Cospuden [04 Transformations and Perspectives. Böhlen/Zwenkau/ /Cospuden]. Mitteldeutsche Braunkohlenrevier. 
TV Sächsiches Burgen- und Heldeland e.V. 2010: Tourenüberblick Kurs 1. Von Leipzig zum Cospudener und Zwenkauer See [Tour overview course 1. From Leipzig to Cospuden and Lake Zwenkau].

Streszczenie: Połaczenie „Jezior Zwenkau-Cospuden" jako jeden z elementów rekultywacji terenu po kopalniach odkrywkowych i jego przyszte znaczenie dla rozwoju tego regionu. Kopalnia odkrywkowa „Böhlen”, zamknięta w 1921 roku, została w 1969 przekształcona w kopalnię odkrywkową „Zwenkau”(,Zw”). W latach siedemdziesiątych, razem z małą sąsiednią kopalnią „Cospuden” (,Cs”), stała się jednym z największych przedsiębiorstw górnictwa węgla brunatnego w Niemczech Środkowych. W ostatnich stuleciach, kopalnie „Zw” i „Cs” miały znaczący wpływ na gospodarkę, postęp techniczny i naukowy tego regionu. Mimo, że znajdowały się one w odrębnych obszarach górniczych, istniały między nimi bardzo bliskie powiązania, zwłaszcza na skutek nakładania się na siebie obszarów obniżenia wód gruntowych. Cała masa zdjętego nadkładu z kopalni „Cospuden”, w górnictwie sektora „Zwenkau”, została zniwelowana i przeznaczona do rekultywacji. Od momentu zakończenia wydobycia węgla brunatnego w regionie Böhlen/Zwenkau/Cospuden, tereny położone na południe od Lipska zostały zasadniczo zmienione. Ubytki ziemi, które kopalnie pozostawiły po sobie, stały się jeziorami. Wzdłuż jezior po- wstały plaże, porty i domy wczasowe. Niemiecka organizacja LMBV, na której obecnie spoczywa odpowiedzialność za odnowienie obszarów po zużytych kopalniach, zaproponowała zupełnie nową perspektywę wykorzystania tego regionu, postrzeganego jako część natury i część dziedzictwa ludzkości. Główny nacisk został położony na rozwój powstałych jezior, zapewnienie przepływu wody oraz jej dobrej jakości. Niektóre z nowych jezior połączone są ze sobą sztucznymi kanałami i śluzami. Dotyczy to również „Jezior Zweknau-Cospuden" (LMBV 2009). W artykule tym opisane są metody zarządzania terenami pogórniczymi na południe od Lipska, ze szczególnym uwzględnieniem połączenia „Jezior Zwenkau-Cospuden”. Zaprezentowane zostały także niezbędne badania na próbkach gruntu z tego obszaru. Na zakończenie ukazano wpływ rekultywacji terenu na jego dalszy rozwój.

Stowa kluczowe: kopalnie odkrywkowe, rekultywacja terenu, sztuczny kanał, „Jeziora Zwenkau-Cospuden".

MS. received February 2012

\author{
Author' address: \\ Katarzyna Gabryś \\ Katedra Geoinżynierii \\ Szkoła Główna Gospodarstwa Wiejskiego \\ ul. Nowoursynowska 166 \\ 02-787 Warszawa \\ Poland \\ e-mail: katarzyna_gabrys@sggw.pl
}

